для формування російської експансіоністської ідеології, залишаючись актуальними тією чи іншою мірою і донині.

\title{
Література:
}

1. Бичурин Н. Я. История первых четырёх ханов из дома Чингисова / Н. Я. Бичурин // История монголов. - М. : Алгоритм, 2008. - С. 5-225.

2. Плано Карпини И. де. История монголов / И. де Плано Карпини // История монголов. - М. : Алгоритм, 2008. - С. 226-306.

3. Хара-Даван Э. Чингиз-хан как полководец и его наследие / Э. Хара-Даван // На стыке континентов и цивилизаций... (из опыта образования и распада империй X-XVI вв.). - М. : ИНСАН, 1996. C. 126.

4. Історія європейської цивілізації. Середньовіччя. Замки. Торговці. Поети / за ред. Умберто Еко. - Харків : Фоліо, 2018. - 763 с.

5. Исаев И. А. История государства и права России : учеб. 2-е изд., перераб. и доп. - М. : Юристъ, 2002. - 768 с.

DOI https://doi.org/10.30525/978-9934-588-92-1-9

\section{FORMATION OF NATIONAL DISTRICTS AND VILLAGE COUNCILS IN THE UKRAINIAN SSR MID-1920S - EARLY 1930S: ORGANIZATIONAL AND LEGAL SUPPORT}

\author{
Kuzmenko N. O. \\ Leading researcher \\ at the Department of European Law and International Integration \\ Institute of Legislation of the Verkhovna Rada of Ukraine \\ Kyiv, Ukraine
}

Currently, representatives of more than 130 nationalities live in Ukraine. Multinational composition of the population of the state requires a systematic and tolerant national policy, which is designed to promote harmonization of international relations, to prevent the emergence of conflicts and contradictions on ethnic ground, etc. Consequently, the interest of scientists to the historical experience of legal regulation of international relations in their own country, and especially the interest to the practice of taking into account the national factor in the process of administrativeterritorial reform becomes of particular importance. 
At the same time, the problems of the history of administrative-territorial reform of Ukraine have already been largely studied by domestic and foreign scientists, in particular, O.Y. Borysyonok, Y.V. Vermenich, R.V. Guban, V.S. Makarchuk, L.I. Riaboshapka, I.M. Skuratovych, I.B. Usenko, B.V. Chirko, O.N. Yarmysh, etc. However, the issue of organizational and legal support of the process of formation of national districts and village councils of the Ukrainian SSR in the mid-1920s and early 1930 were not researched enough and require in-depth scientific study.

The purpose of this scientific publication is to investigate the problems of organizational and legal support for the formation of national districts and village councils in the Ukrainian SSR in the mid-1920 and early 1930. The first administrative-territorial reform in the Ukrainian SSR was carried out in the early 1920. Its content was the transition from a four-stage system of administrative-territorial division (province - county - volost - rural settlement) to three-stage (district - district - rural settlement). As a result of this reform, the number of new administrative-territorial units significantly decreased: instead of 102 counties were formed 53 districts, instead of 1989 volosts - 706 districts. At the same time, the number of village councils decreased from 15,696 to 9,307 [1, c. 90]. Thus, the reform contributed to the simplification and cheapening of the management apparatus, the approximation of authorities to the population, to the formation of new industrialized administrative centers, etc.

However, the creation of new administrative-territorial units was carried out without proper consideration of historical, economic and national factors. This led to the destruction of national- cultural, religious and sociodomestic way of compact population of national minorities. After all, usually socio-economic and socio-cultural life of national minorities in Ukraine had its own specificity. For example, in German settlements, mainly united in one-national volosts, cooperative movement actively developed, agricultural societies, loan and savings offices operated, etc. In addition to primary schools that existed in almost every colony, also vocational schools, agricultural schools, women's gymnasiums and other educational institutions created. There were hospitals, houses for orphans, patients, disabled, deaf, etc. All these institutions were held exclusively by public initiative of German colonists [2, c. 200].

However, as a result of this administrative-territorial reform, all German volost were disbanded and annexed to areas with the other predominant national population (Russian, Ukrainian). At the same time, employees of village councils and district authorities, which included German villages, in most cases did not know German, peculiarities of life of the German population, and sometimes even deliberately ignored the national, cultural, 46 
religious and other needs of German people, what often led to misunderstandings and conflicts. Thus, the report of the NKVD of the USSR of December 22, 1923 «About the political situation in the German colonies of the Varvariv district of Mykolaiv district» directly noted that the attachment of these colonies to village councils with the predominant Russian population led to outbreaks of international hostility that arose on the linguistic ground, as well as through tenure [3, c. 27].

In addition, the implementation of administrative-territorial reform led to the reorganization of educational, medical and philanthropic institutions created by German colonists. These institutions were adapted to the needs of the poorest peasants (mainly Ukrainian and Russian). Most of these institutions, due to the lack of financing or confiscation of property, could not exist at all. Cooperative and credit organizations of colonists were also destroyed [2, c. 200].

All this contributed to the strengthening of emigration sentiment among national minorities. This public mood disturbed greatly the top leadership of the state. In particular, the report note of the Central Commission for National Minorities noted that «Since 1922 to 1924 there was a great desire for emigration to America (Canada) among the German colonists of Ukraine. The total number of those who had emigrated reached 8,000 , not counting children; about 20,000 people wished also to emigrate» [4, арк. 118]. Significant spreading of emigration movement was also among the Jewish population, Greek and others.

As the most effective means to stop the emigration public mood among the representatives of national minorities the party-state leadership saw the creation of national districts and village councils.

It should be noted that at the initial stage of allocation of national districts and village councils was not carried out systematically and on the basis of individual legal acts. Thus, already in June 11, 1924 VUCVK and RNA USR adopted resolution «On the division of areas of Katerynoslav region with the prevailing German population», according to which it was planned to establish new administrative boundaries of some areas of Katerynoslav region in order to differentiate the places of compact residence of Russian and German minorities. As a result, within the Berdyansk district was formed Molochansky (Goldshtadsky) district, comprising the former Bogdanivska and Molochansk volosts, with the predominant German population. In addition, within Melitopol district was singled out Prishybsky district [5].

The legal basis for the process of formation of national administrativeterritorial units was laid down by the Resolution of the RNA of the USSR in August 291924 «About the allocation of national districts and councils» [6, c.97]. In addition, in October 1924 THE THIRD session of the 
VUCVK VIII convocation approved the «Regulation on village councils», which provided for the formation (with the permission of the executive committee) of national village councils with a population of less than 1 thousand Persons [7].

Subsequently, the IV session of the VUCVK VIII convocation (February 15-19, 1925) discussed the report of the Central AdministrativeTerritorial Commission «On Grassroots Zoning» adopted a resolution in which at the legislative level the norm of the population needed to create national administrative-territorial units was reduced compared to ordinary districts and village councils. Thus, for the formation of national village councils normative indicators decreased from 1000 inhabitants to 500, and for national areas from 25000 inhabitants to 10000 [8]. VUCVK and KCNM measures to create national administrative-territorial units were approved by the 9th AllUkrainian Congress of Councils (May 3-10, 1925) [9].

The formation of a regulatory framework for the process of allocation of national administrative-territorial units in Ukraine has had a positive impact on the expansion of the network of national districts and village councils. Thus, if as of April 1, 1925 national village councils in the Ukrainian SSR counted: German - 98, Greek - 26, Bulgarian - 25, Jewish - 19, Polish - 15, Czech - 5, Belarusian - 1, then on October 1, 1926, Russian village councils were created - 312, German - 222, Polish - 119, Moldovan - 52, Greek - 28, Belarusian - 12 [10, c.35]. Just as intensive was the formation of national areas. In particular, only during 1924-1926 biennium by the authorities organizational and legal measures were created five German, two Bulgarian, one Polish district. In general, as a result of the second half of the $1920^{\text {th }}$ allocation of national administrative-territorial units a significant population of national minorities began to live within national districts and village councils, in particular: Greeks - 95.5\%, Bulgarians - 74.9\%, Czechs - 69.6\%, Germans - 58.5\%, Poles - 49.8\%, Russians - 31.8\%, Jews - 25\%, Moldavians $-18.3 \%$ [3, c. 101].

Thus, in the second half of the $1920^{\text {th }}$ was formed organizational and legal framework, which enabled the formation and functioning in the USSR national administrative-territorial units. Formation of national districts and village councils, land management of settlements of national minorities, creation of national educational and cultural institutions, publication of literature in the languages of national minorities was a historically progressive step on the part of the Soviet government. It contributed to the growth of national consciousness of peoples, their political activity and culture. 


\title{
References:
}

1. Скуратович I.M. Адміністративно-територіальний устрій України в 1920-1930-х рр. і його впливи на організацію державного управління: історико-правове дослідження. Х., 2004. 192 с.

2. Кулинич I.М., Кривець Н.В. Нариси з історії німецьких колоній в Україні. К., 1995. 272 с.

3. Німці в Україні. 20-30-ті роки ХX ст. Збірник документів державних архівів України/ Упорядн. Яковлєва Л.В. та ін. К., 1994. 242 c.

4. Центральний державний архів вищих органів влади та управління України (далі - ЦДАВО України). Ф. 1. Оп. 3. Спр. 2504. Арк. 118.

5. Збірник узаконень та розпоряджень Робітничо-селянського уряду України (далі - ЗУ УРСР). 1924. № 13. Ст. 130.

6. Итоги работы среди национальных меньшинств на Украине: К 10-й годовщине Октябрьской революции. По материалам Центральной Комиссии национальных меньшинств при ВУЦИК. Харьков, 1927. 167 с.

7. ЗУ УРСР. 1924. № 46. Ст. 279.

8. ЗУ УРСР. 1925. № 13-14. Ст. 99.

9. Вісті ВУЦВК. 1925. 7 травня.

10. Проблема районирования на Украине / Под ред. А.И. Буценка. Харьков, 1926. 158 с.

DOI https://doi.org/10.30525/978-9934-588-92-1-10

\section{ПОНЯТІЙНО-ПРАВОВЕ МИСЛЕННЯ У ДАВНІЙ ГРЕЦЇ̈: РАННЬОЕЛЛІНІСТИЧНИЙ СКЕПТИЦИЗМ}

\author{
Кучеренко Д. С. \\ консультант з юридичних питань \\ ТОВ «КОМРЕЦЬ» \\ м. Запоріжжя, Украӥна
}

Скептицизм (грец. skeptikos - той, хто розглядає, досліджує, мислить, сумнівається, від skeptomai - розглядаю, досліджую, мислю, сумніваюся) - філософський напрям, заснований Пірроном Елідським (бл. 360 до н.е.-бл. 270 до н. е.). До найвідоміших представників 